\title{
DEVELOPMENT IN ADVERSITY: SOUTH AFRICA'S DEFENCE INDUSTRIAL PARTICIPATION IN PERSPECTIVE
}

\author{
Johan J. van Dyk, Richard Haines, and \\ Geoffrey Wood $^{1}$ \\ NMMU
}

\begin{abstract}
Defence industrial participation (DIP) is a form of countertrade and falls in the sub-category of (defence) offsets. The South African DIP programme played a developmental role in the country's defence industrial base (DIB), arresting its steady decline since the 1980s. This article discusses the perceived nonachievement of the 1997 DIP objectives and the reality of its manifestations over a 12-year period (2000-2012). It is argued that the DIP tripled the gross national product and improved the economy through the retention of some 58000 jobs. However, the 2014 Defence Review paves the way for a new defence industrial dispensation. Notwithstanding, there is a need to explore the concomitant ambiguity that exists between perceptions of countertrade and offsets as tradedistorting practices and as value-adding prospects, and to ascertain how this reciprocal trade mechanism could be used better to promote the developmental aims and objectives of governments.
\end{abstract}

\section{Introduction}

Countertrade internationally, manifests in many forms. ${ }^{2}$ The most popular form of countertrade since the mid-1990s is offsets that occur in both defence and civil procurement. Offsets are procurement advantages used by governments procuring products and services from abroad to seek various forms of reciprocal benefits for a country's domestic industry in return for the weapons or high-value

Scientia Militaria, South African Journal of Military Studies, Vol 44, No. 2, 2016, pp. 146-162. doi : $10.5787 / 44-2-1179$ civil purchases (e.g. passenger aircraft). ${ }^{3}$ As a result of the biggest defence transaction in South Africa, the Strategic Defence Package (SDP) of December 1999, incurred R15 billion worth of DIP obligations. This article 
focuses on the DIP stemming from the SDP.

Approximately 40 percent of countries applying the principle of reciprocity, use various purposely structured government procurement programmes to procure goods and services from abroad. ${ }^{4}$ Although defence-related countertrade (hereafter referred to as 'defence offsets'), in particular, has been controversial in many contexts, it may play a positive developmental role, including developing and maintaining a defence industrial base (DIB) in those countries that have the capability. Despite defence offsets' developmental prospects, there are several opposing views on its use. ${ }^{5}$

South Africa has two sets of industrial participation policies and practices. One is the DIP, managed exclusively by Armscor, South Africa's acquisition agency. DIP favours pursuing defence industry development objectives. The other is the National Industrial Participation Programme (NIPP), managed independently by the Department of Trade and Industry (dti) that focuses primarily on civil industry. Both programmes (DIP and NIPP) are often erroneously conflated and collectively referred to as 'offsets', which may create the impression that they are synonymous. The objectives of both programmes in terms of the percentage obligation, discharge and penalty requirements compare well with international best practice. ${ }^{6}$

According to the 2012 study by Avascent, estimates show that from 2005 to 2011, approximately USD 214 billion in total offsets obligations were generated worldwide. ${ }^{7}$ Although general indications are that defence spending has been in a constant decline since $2006,{ }^{8}$ there are indications pointing towards an upward swing as from 2018. ${ }^{9}$ This growth in defence spending will inevitably cause increased countertrade and offset activities.

Defence spending in South Africa had declined from a high of 15 percent of the gross domestic product (GDP) in the mid-1980s to around 1,7 percent by 2013. This includes the SDP's loan repayment. ${ }^{10}$ However, the 2014 Defence Review states that this level of defence spending is too low to re-stock the South African National Defence Force (SANDF), and a call was made to increase this to around 2,4 percent of the GDP. ${ }^{11}$ This would inevitably cause an increase in DIP and NIPP transactions and, therefore, it is predicted that South Africa will remain in the top twenty offset markets. ${ }^{12}$

\section{Defence industrial participation in the context of countertrade}


Since its inception in 1988, the Armscor countertrade programme has used the reciprocity principles of leveraged government procurement. ${ }^{13}$ Reciprocity principles solicit countertrade benefits in a structured manner. ${ }^{14}$ Between 1988 and 1999, Armscor entered into various countertrade transactions that manifested as counter-purchased goods for export to the value of R5,1 billion. ${ }^{15}$

Until late 1996, Armscor was the only government entity in South Africa that required countertrade on foreign procurement contracts. However, on 30 April 1997, Cabinet ratified Parliament's 1996 decision to allow the dti to impose the NIPP at national level. ${ }^{16}$ This necessitated redrafting the Armscor countertrade policy that had been in use since the late 1980s into a new defence industrial participation policy directly aimed at retaining, maintaining, and further developing the local DIB.

In the South African countertrade programme, the DIP is highly prescriptive about types of activities and what qualifies for DIP (offset) credit. ${ }^{17}$ In this instance, 'prescriptive' refers particularly to Armscor's expectation that the potential supplier should propose a combination of DIP activities in the form of work share on the purchased equipment (co-production), technology transfer (including training), investments (capital infrastructure improvement, equipment, tooling, test benches, etc.) and the export of defence-related products. ${ }^{18}$ The DIP overshadowed the less structured NIPP programme that was far less successful with many an aborted civil venture. ${ }^{19}$

\section{The 1999 strategic defence package in perspective}

The development of the South African DIB commenced in earnest as from the mid-1960s. ${ }^{20}$ For example, Henk notes that by then, there were already approximately 1000 defence-related companies, by the mid-1980s this figure was over 2000 , and by the end of the 1980s, it was approximately $3000 .^{21}$ Botha records that by the mid-1980s, Armscor had concluded contracts with approximately 2700 private sector companies and the armaments industry employed 131750 people. $^{22}$ This figure represented 8,3 percent of the total number of employees in the manufacturing sector at that stage. By the mid-1980s, the industry had acquired the ability to design, reverse-engineer, manufacture, produce, maintain, refurbish, upgrade and modify a wide range of defence equipment. ${ }^{23}$

The defence industry's rather rapid development and need to acquire superior military technologies can be linked to the war in Angola where the South African forces were confronted with sophisticated Russian-made military equipment. ${ }^{24}$ On the other hand, the various UN embargoes against South Africa 
arguably accelerated this growth. However, from the late 1980s, as a result of FW de Klerk's reform initiatives that led to the release of Nelson Mandela and the disbanding of all South Africa's political resistance movements, there were no major defence procurement activities ${ }^{25}$ and according to Engelbrecht, the local defence industry shrank from "shark to minnow". ${ }^{26}$ This decline continued after the African National Congress (ANC) came to power in 1994 but was stopped with the award of the 1999 SDP contracts and thus provided the DIB with a desperately needed lifeline. ${ }^{27}$

The Department of Defence's (DoD's) 1996 Defence White Paper and the 1997 Defence Review contain specific government mandates to re-equip the SANDF. The arms of service most in need were the South African navy and the air force. The government emphasised South Africa's ability to be able to defend itself against various threats to national security. ${ }^{28}$ The DoD's 1999 White Paper on the defence-related industry acknowledges the decline in the local defence industrial base. $^{29}$

The SDP process commenced in 1997 resulting in a series of tender invitations and evaluations during 1998, followed by strenuous negotiations during 1999. ${ }^{30}$ The cabinet approved the final recommendation on 1 December 1999 to award the SDP contracts with a combined base value of R30 289 billion, ${ }^{31}$ and a base DIP commitment of R15 326 billion.

The SDP contracts included patrol corvettes and submarines from Germany, helicopters from the Unite Kingdom and Italy, Hawk aircrafts from the United Kingdom, and Gripen aircrafts from Sweden. The DIP stemming from these contracts was to be discharged between 2000 and 2007/8. However, the direct DIP activities of the Hawk and Gripen aircrafts were linked to their respectively delivery schedules, to be finalised by 2009 and 2011 respectively, with all the technologies and indirect activities by 2007. Due to the delay in contracting the corvettes' surface-to-surface missiles from MBDA, France, there is an amount of R949 million that will only be discharged by $2016 .{ }^{32}$

The 2014 Defence Review reaffirms that the SANDF must be appropriately equipped, resourced and trained to execute successful multi-role operations across all areas of potential conflict. ${ }^{33}$ The Review confirms that the defence force remains in a critical state of decline characterised by an imbalance between its force capabilities, and the unaffordability of many of its main operating systems. ${ }^{34}$ The current balance of expenditure between personnel, operating and capital is both "severely disjointed and institutionally crippling" and mismatches the actual requirement for equipment. ${ }^{35}$ 
However, arresting the decline in South Africa's DIB will not happen immediately; it will take at least five years, and another five years before a 'limited sustainable capability' can be reached. ${ }^{36}$

\section{Manifestation of the 1997 defence industrial participation objectives}

The 1997 DIP policy primarily focused on a retention-type strategy rather than an expansion-type one largely because of the serious decline in the DIB since the late 1980s. Being able to create additional capabilities and jobs (stated policy objectives) would have been a bonus. The DIP policy was aligned with the respective Defence White Paper of 1996, the Defence Review of 1997, and the White Paper on the Defence-related Industry of 1999. ${ }^{37}$

The DIP evaluation guidelines of the SDP issued in 1998 to potential suppliers stated the various strategically important aspects required by the SANDF. However, DIP was non-prescriptive about the activities within which suppliers had to engage with the South African Defence Industry (SADI). The only exception was the corvette combat suite that was not a DIP prescription, but a formal tender requirement. ${ }^{38}$ With hindsight, many more strategic requirements should have been included in the respective SDP tenders. ${ }^{39}$

The 2014 Aerospace Maritime and Defence (AMD) review on the effect of DIP acknowledges that an extended DIP negotiation process could have resulted in more effective structuring. Instead, there was no manufacturing framework and no related national technology to guide obligors to align industrial activities with national priorities. The 'compartmentalisation' of DIP and NIP (National Industrial Participation Programme) did not contribute to the envisaged approach to industrial participation. ${ }^{40}$

Notwithstanding some of the criticism recorded, there is clear evidence that the DIP objectives were indeed served, arguably not optimally. Nevertheless, this article postulates a contrary view to those of particularly Brauer and Dunne ${ }^{41}$ supported by, for example, Holden and Van Vuuren, ${ }^{42}$ as well as CrawfordBrowne, ${ }^{43}$ who postulate that offset seldom yields any long-term benefits. From a purely economic impact assessment (EIA) point of view, the DIP achieved the following policy objectives:

- For example 7970 direct jobs, ${ }^{44}$ with 20043 indirect jobs and 30989 induced jobs were retained - a total of $59002 . .^{45}$ It is therefore argued that the DIP objective of retaining jobs was thus met and further losses stopped. ${ }^{46}$ 
- $\quad$ Promoting exports was another DIP policy objective. In this regard, DIP credits for R9,9 billion were granted by 2012. During the proceedings of the Arms Procurement Commission (APC ${ }^{47}$ ) of Inquiry during 2013 to 2014, there were several testimonies of DIP contributions to the DIB with concomitant sustainability. ${ }^{48}$

- Another DIP policy objective was for 'like-for-like technology transfer'. In this instance, Armscor awarded DIP credits to the value of R4 billion $^{49}, 28$ percent of the total DIP commitment. Gerber ${ }^{50}$ attributes the growth of SADI exports to these technology transfers. ${ }^{51}$ Although SADI companies were entrenched into global supply chains, there are concerns that the relationships with European defence companies could have been asymmetrical in the sense that some of the exported goods were clearly at a lower technological level than the goods imported. ${ }^{52}$

At the SDP equipment-specific level, the following is recorded in respect of key DIP activities that were caused by DIP obligations stemming from the various programmes. The various media reports and periodical publications covering the basis of these observations are, to say the least, quite vast, which makes detailed referencing impractical. ${ }^{53}$ The following are examples of those activities that are related to the DIP objective of sustainability:

- In the corvette programme, for example, the combat suite retained a wide array of local technologically advanced capabilities also at various sub-contractor levels - command and control electronics, sensoric and armament. This included Denel's surface to air missile system (Umkhonto), which led the Finish navy ${ }^{54}$ to select the same missile system. Locally produced parts of the corvette platform are still ordered for export. ${ }^{55}$ Under this programme, the DIP delivered R1,6 billion in sales and exports, R520 million in technology transfers and R26 million in investments.

- The DIP submarine contract resulted in a technology transfer that enabled Laingsdale Engineering to manufacture Junghans (Germany) self-destruct fuses for $40 \mathrm{~mm}$ grenades. ${ }^{56}$ Submarine radar warning receivers were delivered to Greece, Portugal and South Korea, and electronic support measures (ESM) systems for German navy mine-hunters. ${ }^{57}$ Under this programme, the DIP delivered R867 million in sales and exports, R364 million in technology transfers and R8 million in investments. 
- Denel Aviation (later Aerostructures) manufactured 25 Agusta A109 light utility helicopters (LUH) - this allowed them to undertake structural modifications later. ${ }^{58}$ Turbomeca Africa (TMA) produced the gearbox of the LUH and continues to provide maintenance support to several South African Air Force (SAAF) aircraft engines and sub-systems. Various sensoric equipment, and sand filters were supplied locally. Rotor blades manufactured for the SAAF A109 helicopters were subsequently also exported to Agusta, Italy. ${ }^{59}$ Under this programme, the DIP delivered R676 million in sales and exports, R487 million in technology transfers and R31 million in investments.

- $\quad$ On the Hawk programme, Denel was contracted for the component manufacture and the final assembly of the aircraft. Denel's munitions group (PMP) received a number of major contracts from BAE Systems. PMP also acquired the licence from BAE Systems to produce the ammunition (30mm) for the Hawk's cannon, which is being exported worldwide. PMP also acquired rights for the ejection seat cartridges ('shelf-life-expire' items) for both Hawk and Gripen. The Hawk's 'mission design authority' technology was transferred to Denel, allowing several kinds of weapon systems integration. ${ }^{60}$ Denel remains in a position to carry out maintenance and any modification work that may be required by the SAAF. Various follow-on DIP contracts have been received by Aerosud from Airbus and Boeing. Saab Grintek secured export contracts for health and usage monitoring systems (HUMS) for the Hawks operated by the Royal Air Force, the NATO Flying Training Centre in Canada, the Royal Australian air force and the Indian air force. HUMS will be a standard feature in all future Hawk orders. ${ }^{61}$ Under this programme, the DIP delivered R3,3 billion in sales and exports, R973 million in technology transfers and R17 million in investments.

- The contribution of the Gripen to the sustainability of the SADI is quite varied. One of the high credit value activities was the Skills Transfer and Technology Programme (STTP) with Denel. ${ }^{62}$ Under the STTP, some 100 aircraft manufacturing staff and engineers were trained in Sweden. ${ }^{63}$ Because of this particular capability, Denel Aerostructures was awarded a part production share in the Airbus A400M military cargo aircraft. ${ }^{64}$ Denel Aerostructures is the only 
Tier 1 supplier outside Europe of manufactured parts to the A400M. In June 2014, Airbus Military placed a third multimillion-rand contract with Denel. According to Schür, ${ }^{65}$ Denel dramatically changed the way it used to approach manufacturing, as a direct result of being exposed to different technologies and training under the various DIP programmes.

- Since 2003, Denel Optronics (later Carl Zeiss Optronics - now Cassidian) secured contracts for its helmet-mounted tracking system (HTS) for the Gripen, which led to an export contract in May 2007 for the Eurofighter-Typhoon aircraft valued at R200 million. Seven hundred HTS units were reported to be manufactured over a four- to five-year period, that is 2007 to $2012 .{ }^{66}$ Optronics also manufactured the attack periscopes for the navy's submarines, as well as providing maintenance support. The Council for Scientific and Industrial Research (CSIR) obtained much-needed technical information on the Saab/Ericsson, Swedish-produced PS-05A longrange radar. Tactical simulation development of digital models and data links for radar warning receivers were also linked to the CSIR's virtual ground-based air defence system demonstrator (in collaboration with Denel Dynamics). This DIP activity positioned the CSIR to help develop a local capability to understand the Gripen's complex $4^{\text {th }}$-generation digital flight control system, needed for the successful integration of the Denel-manufactured $5^{\text {th }}$ generation air-to-air missile system (A-Darter). ${ }^{67}$

- In 2005, Saab acquired a 70,3 percent equity in Grintek and subsequently boosted the former Grintek's turnover with USD 16 million. Saab Grintek is Sweden's biggest operation outside Sweden. It employs 1064 people, many highly technically skilled. The company boasts with a turnover of R1,4 billion, 60 percent of which came from exports in 2011. It has become a manufacturing base for the Swedish group in Africa, supplying and serving countries in East, West and Southern Africa. The company employs highly skilled technical staff and approximately 10 percent of its turnover is re-invested in Research and Development (R\&D) ${ }^{68}$ Saab Grintek participated extensively in system design and optimisation of the Gripen radar and electronic warfare systems to meet the contracted SAAF specifications. These upgrades are now an integral part of the Swedish, Hungarian, Czech and Thai air forces. ${ }^{69}$ Saab 
Grintek will supply all microwave components and sub-systems for all future Gripens. ${ }^{70}$ Under this programme, the DIP delivered R3,2 billion in sales and exports, R1,75 billion in technology transfers and R173 million in investments.

- The maritime helicopter's DIP resulted in R519 million in sales and exports, R31 million in technology transfers and R3 million in investments. The DIP-related activities stemming from these figures were mainly in the electronic sectors of (Saab) Grintek and (Cassidian) Denel Optronics. Aerosud was contracted to supply engineering services for the infrared suppression system and armoured crew seat for the Lynx helicopter, while Saab Grintek was contracted to supply electronic warfare equipment. Aerosud and Saab Grintek appear to be the preferred suppliers of this equipment - also for the export market.

Therefore, the DIP was successful and sustainable in many instances on many levels through sales and exports, technology transfer, investments, and job creation as noted through the above-mentioned observations.

\section{The developmental importance of defence industrial participation}

An EIA was done on the DIP to determine its productive industrial importance. The National Social Accounting Matrix (NSAM) applying the Standard Industrial Classification (SIC) code 38 was used for this. The NSAM is a database consisting of computable tables that reflect a given economy's structure. ${ }^{71}$ Since it is compiled for a specific period, it describes the economy for that particular period. ${ }^{72}$ Due to the extensive backward and forward links inherent in the social accounting matrix, the resulting 'ripples' from the initial intervention would flow into other sectors. Eventually, these 'ripples' could be totalled to determine the effect on economic production, GDP, employment and household income. For example, the total expenditure on the range of SDP equipment over the period 2000 to 2012 was used to calculate the economic influence on the wider economy. The results of the DIP's macroeconomic effect (at 2013 prices, based on the DIP info published by Armscor in their 2012/13 Annual Report) are summarised below in Table 1.

Production is the process through which labour and assets are used to transform inputs of goods and services into outputs of other goods and services. The impact assessment measured the expected changes in production as a result of the respective DIP projects. Between 2000 and 2012, the total value of the DIP of 
R14,17 billion was mainly invested in manufacturing and the transfer of technology. This implies a further benefit to the economy in the form of household income and its effects on spending, creating a demand for consumer goods and services, investment and potential growth. Secondly, gross national product (GNP) is the market value of all final goods and services produced within a country in a given period. The assessment therefore measured the effect of the various DIP projects on the South African economy, and concluded that the DIP raised the level of economic activity by R3.03 for every DIP rand.

\begin{tabular}{|l|c|r|r|r|}
\hline \multirow{2}{*}{ Variable } & \multicolumn{2}{|c|}{ Effect of the DIP on the South African economy - 2013 prices } \\
\cline { 2 - 5 } & $\begin{array}{l}\text { Direct } \\
\text { effect }\end{array}$ & Indirect effect & $\begin{array}{c}\text { Induced } \\
\text { effect }\end{array}$ & Total effect \\
\hline $\begin{array}{l}\text { Production } \\
\text { (R million) }\end{array}$ & 14165.00 & 11857.95 & 16922.57 & 42945.53 \\
\hline $\begin{array}{l}\text { Gross national } \\
\text { product } \\
\text { (R million) }\end{array}$ & 6142.68 & 4568.04 & 7484.00 & 18194.72 \\
\hline $\begin{array}{l}\text { Employment } \\
\text { opportunities } \\
\text { (person year) }\end{array}$ & 7970 & 20043 & 30989 & 59002 \\
\hline $\begin{array}{l}\text { Employee } \\
\text { income (R } \\
\text { million) }\end{array}$ & 2591.86 & 2120.70 & 3320.22 & 8032.79 \\
\hline
\end{tabular}

Table 1: The economic impact assessment of the SDP's DIP 73

Based on the DIP's EIA, the total value of income earned by those employed as a result of the DIP is estimated at about R8,03 billion. Individuals and households used this income to fund daily consumer goods and services, such as education, transport and housing. All of these are important elements of developmental discourse.

\section{Conclusion}

The DIP policy of 1 April 1997 (A-POL-6100) endeavoured to underwrite the developmental aims and objectives of Armscor in relation to the SADI as contained in the 1996 Defence Review, the White Papers of 1997 and 1999, and in legislation (i.e. Armaments Development and Production Act 57 of 1968, as amended - replaced by the Armaments Corporation of South Africa, Limited Act, 
Act 51 of 2003). Although, by law, Armscor remains largely in charge of the DIB process, the 2014 Defence Review makes it clear that there needs to be much better alignment of the DIB development strategies with national industrial development imperatives. Planning around the utilisation and optimisation of the DIP in relation to the further development of the DIB can clearly no longer occur in insolation. This has to include the creation of a much closer collaboration between the DIP (Armscor) and NIP (the DTI) custodians.

DIP directly caused a substantial number of mergers between prominent European defence companies ${ }^{74}$ and SADI companies. As a result, SADI companies have been entrenched in the international global supply chains of various original equipment manufacturers (OEMs), which contributed to sustainability and a stabilised DIB. However, there are some concerns that the technology base of the DIB has the potential to be compromised. ${ }^{75}$

Despite the various positive achievements of the 1997 DIP policy objectives, it remains criticised for not having optimised the industrial prospects for the broader industrial base. If a properly contracted DIP baseline is required before tender award (as alluded to by the 2014 Defence Review), clearly bidders will require additional time to conclude binding DIP contracts with SADI before signing contracts with Armscor. The DoD and Armscor will have to be much bolder in their DIP requirement statements at tendering if they wish to build on technologically advanced capabilities in certain sectors of the DIB. This will require a better, more detailed procurement and acquisition plan that must be incorporated into the DoD's strategic capital acquisition master plan (SCAMP).

Although SADI is the $17^{\text {th }}$ largest exporter of defence equipment, ${ }^{76}$ the 2014 Review $^{77}$ emphasises the need for much more efficient links with related government initiatives. This is necessary to ascertain how DIP (and its NIPP counterpart) as a reciprocal trade mechanism can be better used to promote the developmental aims and objectives of the government, and in particular the DIB. Therefore, it is clear that further research, reviews and revisions are required in respect of South Africa's industrial participation dispensation.

Finally, the manner in which DIP was structured in 1997, contractually applied in 1999 and subsequently executed between 2000 and 2012, indicates that it was primarily focused on retention rather than growth. ${ }^{78}$ Based on the respective manifestations of DIP activities across SADI and the EIA results, it is postulated that the DIP (and thus countertrade in its broader sense), despite its developmental adversity, can indeed be used as a development tool for industry (through work share and technology transfer), the economy (through contributing to the 
productive industrial sector) and human capital (through contributing skills development and training). ${ }^{79}$ The 2014 Armscor DIP policy review contains basically the same goals and objectives that were adopted in 1997.

\section{Endnotes}

${ }^{1}$ Johan J van Dyk is a $2015 \mathrm{PhD}$ graduate in Development Studies from Nelson Mandela Metropolitan University (NMMU), South Africa. Previously at Armscor Countertrade division (until 2001), Denel SOC Ltd (until 2009) with access to details of all the countertrade transactions and Denel's international offsets commitments. The SDP's detailed DIP transactional information is otherwise protected by commercial non-disclosure agreements. This article is based on research of Van Dyk's PhD thesis, "Countertrade as a development tool: A comparative analytical approach, supervised by Prof Richard Haines, head of the Development Studies Department at NMMU, and Prof Geoffrey Wood at Warwick Business School, University of Warwick, UK,

2 JH Coetzer. International countertrade contracts: Principles and practice. Pretoria: Info Africa Nova, 1995.

${ }^{3}$ MA Yülek \& TK Taylor. Designing public procurement policy in developing countries. How to foster technology transfer and industrialization in the global economy. New York, NY: Springer, 2012.

${ }^{4}$ The Country Quarterly Bulletin published by CTO Services, UK, contains a comprehensive set of all the countertrade-related policies and guidelines of around 80 countries. See Countertrade \& Offsets (CTO). "Country Quarterly Bulletin”. July 2012. CTO Data Services. <http://www.cto-offset.com> Accessed on 1 December 2016.

${ }^{5}$ Some stem from economic considerations (e.g. Brauer, Dunne, Holden, Van Vuuren), while others view it as a conduit for corruption (e.g. CrawfordBrowne).

${ }^{6}$ Report on the Joint Investigation into the Strategic Defence Procurement Packages. The joint investigation was done by the Public Protector, the Auditor-General and National Director of Public Prosecutions, and submitted their Report to Parliament on 14 November 2001. <http://www.gov.za/sites/www.gov.za/files/Joint_Investigation_Report_0.pd f> Accessed on 1 December 2016. CTO op. cit., p. 2.

${ }^{7}$ Avascent, Washington, DC, is, according to their website, the leading provider of business consulting services to firms operating in industries at the intersection of business, technology, and government policy - available at <http://www.avascent.com> Accessed on 1 December 2016.

${ }^{8}$ SIPRI. Yearbook: Armament, disarmament and international security. Oxford: Oxford University Press, 2013. 
${ }^{9} \mathrm{~V}$ Pavlak \& G Odden. Lessons in A\&D and auto supply chain strategy, Part 2: Focus on competitive advantage. KPMG special report. Published by UTC via Defense Industry Daily. 31 March 2014.

${ }^{10}$ AR Donaldson. A.R. Deputy Director General: National Treasury. The Arms Procurement Commission (APC) testimony from 9/4/2014 to 11/4/2014. <http://www.armscomm.gov.za/hearings > Accessed on 15 May 2014.

${ }^{11}$ G Martins. "Military Command needs to get on board Defence Review" DefenceWeb. 8 August 2014. <http://www.defenceweb.co.za/index.php?option=com_content\&view=articl e\&id=35786:military-command-needs-to-get-on-board-defencereview\&catid=111:sa-defence > Accessed 1 December 2016.

${ }^{12}$ D Kimla. Military offsets \& in-country industrialisation. Slideshow presentation. Market Insight. Top 20 Military Offsets Markets. Frost\&Sullivan. March 2013. < http://www.frost.com/prod/servlet/cio/275947347> Accessed on 1 December 2016.

13 JJ van Dyk. "An evaluation of the South African Department of Defence's policy on defence industrial participation ('DIP'), as a defence industrial development mechanism". Master's dissertation. NMMU, 2008.

14 JP Dunne \& G Lamb. Defense industrial participation: The South African experience. 2003.

<http://carecon.org.uk/Armsproduction/Papers/DunneLamb.pdf> Accessed on 1 December 2016; JP Dunne \& G Lamb. "Defense industrial participation: The South African experience”. In J Brauer \& JP Dunne (eds), Arms trade and economic development: Theory, policy, and cases in arms trade offsets, London: Routledge, 2004, 284-298.

15 Armscor. Annual Reports 1999/2000 up until 2012/13. <http://www.armscor.co.za> Accessed 1 December 2016. PG Batchelor and S. Willett. Disarmament and defence industrial adjustment in South Africa. Oxford: Oxford University Press, 1998. JJ van Dyk. "South Africa's industrial participation programme in perspective". In Z Warwar (ed.), Panorama da pratica do offset no Brazil, Brasilia: Livraria Suspensa, 2004, 251-288. JB de Beer. APC testimony on 4/3/2014, 5/3/2014 and 6/3/2014. Available at <http://www.armscomm.gov.za/hearings > Accessed on 5 April 2014.

${ }^{16}$ See <http://www.thedti.gov.za> (the 1996/7 guidelines were revised in 2008 and in 2013.)

${ }^{17} \mathrm{~K}$ Balakrishnan. "Evaluating the effectiveness of offsets as a mechanism for promoting Malaysian defence industrial and technological development". PhD thesis. Cranfield University, 2007. De Beer op. cit., p. 2. PD Burger. APC testimony on 12/3/2014. Available at: <http://www.armscomm.gov.za/hearings > Accessed on 5 April 2014. 
${ }^{18}$ De Beer op. cit., p. 2.

${ }^{19} \mathrm{G}$ Wellmann. "An evaluation of the Augusta Westland: Filk Gold Chains in South Africa National Industrial Participation Project”. Master's thesis. University of Port Elizabeth, 2004; Also, "An evaluation of the BAE/SAAB South African Royal Manufacturing Project in Virginia, Free State province: A case study of the implementation of the South African Defence offsets". D Phil thesis. NMMU, 2010.

${ }^{20}$ I Liebenberg \& L Barnard. "Arms acquisition and procurement in South Africa: The socio-history of arms deals with reference to attitudes, strengths and limitations in decision-making (1935-2004) (II)". Journal for Contemporary History. 31. 1. 2006. 99-112.

${ }^{21}$ D Henk. South Africa's armaments industry: Continuity and change after a decade of majority rule. Lanham. MD: Universal Press of America, 2006.

22 D Botha. "The arms deal controversy". African Security Review 12(3) 2003 .; D Botha. Offsetting the cost of SA's strategic defence package. ISS Paper 75. July 2003. < https://issafrica.org/uploads/paper75.pdf > Accessed on 15 March 2012.

${ }^{23}$ Willet \& Batchelor op. cit., p. 3 AMD. 2006. "The South African Defence related industries study report".<https://observatoiredefense.files.wordpress.com/2011/01/industry_s tudy_textbook.pdf > Accessed on 1 December 2016.

${ }^{24}$ S Boden, B Smith \& M Enright. Armscor: Life after apartheid. Boston, MA: Harvard Business School, 1996. Henk op. cit., p. 3; Liebenberg \& Barnard op. cit., p. 3.

25 J Cilliers. "Defence acquisitions - Unpacking the package deals". ISS occasional paper no. 29. March 1998. <http://www.iss.co.za/pubs/papers/29/paper29.html> Accessed on 2 February 2012. (Cilliers is the executive director, South African Institute for Security Studies.

${ }^{26}$ L Engelbrecht. Offsets bleed local industry. IT Web. 25 October 2006. <http://www.itweb.co.za/index.php?option=com_content\&view=article\&id= 118531> Accessed 1 December 2016.

${ }^{27}$ AMD. "DIP study paper". <http://www.amd.org.za/documents> Accessed on 8 August 2014.

${ }^{28}$ Cilliers op. cit., p. 3.

${ }^{30}$ Auditor General op. cit., p. 2. D Griesel. Testimony at the APC on 30/9/2013, 1/10/2013 and 2/10/2013. Available at: <http://www.armscomm.gov.za/hearings> Accessed on 15 January 2014.

${ }^{31}$ Holden and Van Vuuren estimate the final cost in the region of R70,6 billion against National Treasury's 2014 figure of R46,6 billion (Donaldson op. cit., 
p. 2). See $\mathrm{P}$ Holden \& $\mathrm{H}$ van Vuuren. The devil in the detail: How the arms deal changed everything. Johannesburg: Jonathan Ball, 2011.

${ }^{32}$ De Beer op. cit., p. 3; Burger op. cit., p. 2.

${ }^{33}$ The 2014 defence review drafting and consultative processes commenced in 2012 under the leadership of Roelf Meyer, who was appointed by the Minister of Defence (and Military Veterans). Cabinet formally approved the 2014 Defence Review in March 2014. See <http://www.dod.mil.za> and <http://sadefencereview2012.org.za>. [The 2014 review replaces the 1997 version in totality.]

${ }^{34}$ See Defence Review 2014: par 38:[x].

${ }^{35}$ See Defence Review 2014: paragraphs 48 and 52:9-9; also J Cilliers. The 2014 South African Defence Review. Rebuilding after years of abuse, neglect and decay. Policy brief 56. June 2014. Institute for Security Studies.

${ }^{36}$ See Defence Review 2014: par 53:9-9.

${ }^{37} \mathrm{JJ}$ van Dyk. "Countertrade as a development tool: An analytical approach". PhD thesis. NMMU, 2015.

${ }^{38}$ De Beer op. cit., p. 3; Burger op. cit., p. 2.

${ }^{39}$ Van Dyk op. cit., p. 4.

${ }^{40}$ Van Dyk's PhD study included as respondents, O Schür, P Gerber, and H RömerHeitman. O Schür, SAAF Brigadier General (ret.) with experience in the DoD acquisition process, thereafter joining Denel Corporate, a major DIP participant involved with all the SDP equipment. Currently with a privately owned aerospace group, Safomar, active with SADI strategy and planning with AMD, and involved in the 2014 Defence Review's redrafting. P Gerber, SAAF Brigadier General (ret) worked with DIP and countertrade until 2005, thereafter with the Grintek Group and then Aerosud. Also involved in redrafting the 2014 Defence Review with AMD. He was contributor to the 1997 DIP policy. H Römer-Heitman, is a prominent South African defence analyst. ET Cavalini \& DJ Fourie. "Offset agreements in the defence arena. International practices and South African legislation and policies" African Journal of Public Affairs 6/3 September. 2013.

${ }^{41}$ J Brauer \& JP Dunne (eds) op. cit.; J Brauer \& JP Dunne. "Arms trade offsets: What do we know?" In Coyne, Christopher J. and Rachel L. Mathers (eds) Handbook on the Political Economy of War, Cheltenham, UK: Edward Elgar, 2011, 243-265.

${ }^{42}$ Holden and Van Vuuren op. cit., p. 3.

${ }^{43} \mathrm{~T}$ Crawford-Browne. APC testimony between 6/10/2014 and 9/10/2014. Available at: <http://www.armscomm.gov.za/hearings> Accessed on 15 October 2014.

${ }^{44}$ In his testimony to the APC, Pieter Burger from Armscor (2014) indicated that just under 12000 jobs were retained/created in 80 percent of the SADI companies that were beneficiaries of the SDP's DIP. Burger op. cit., p. 3. 
45 This figure excludes other pronouncements as related to the estimated NIPP jobs of 65000 .

${ }^{46} \mathrm{P}$ Batchelor \& P Dunne. Industrial participation, investment and growth: The case of South Africa's defence related industry. Development Southern Africa Vol. 17, No. 3 (September), pp 417-435. Van Dyk op. cit., p 4.

${ }^{47}$ Arms Procurement Commission of Inquiry, South Africa (APC). All the hearing transcripts and government documentation submitted to the APC are available at: 〈http://www.armscomm.gov.za/hearings〉.

${ }^{48}$ Armscor op. cit., p. 2; Burger op. cit., p. 3; Gerber op. cit., p. 5; Van Dyk op. cit., p. 4.

${ }^{49}$ PD Burger. APC testimony on 12/3/2014. Available at: <http://www.armscomm.gov.za/hearings > Accessed on 5 April 2014.

${ }^{50}$ Gerber op. cit., p. 5; see also Endnote 55 op. cit., p. 13.

${ }^{51}$ South African Defence Industry (SADI) statistical survey done by AMD in 2011. AMD op. cit., p. 3.

52 An example of this would be the PMP brass exports for small calibre ammunition production in the UK under the Hawk's DIP obligations.

53 The media sources consulted include, for example, the Creamer Media's Research Channel (<http://www.researchchannel.co.za $>$ ), Creamer Media's

Engineering News, defenceWeb (<http://www.defenceWeb.co.za $>$ ). The website by Richard Young has a database containing over 12000 articles on the SDP covering the 'arms deal'. Available at: $<$ http://armsdeal-vpo.co.za $>$ Accessed between 2008 and 2014.

54 This included through life cycle support to these missile systems, also for the SA navy.

55 JEG Kammerman. Testimony at the APC on 26/5/2014 and 27/5/2014. Available at: 〈http://www.armscomm.gov.za/hearings> Accessed on 15 June 2014.

56 The significance of this activity lies in the improved export marketability of these grenades, as they are compliant with the Wassenaar Agreement that requires certain types of ammunition to be fitted with self-destruct fuses.

${ }^{57} \mathrm{R}$ Vermeulen. Testimony at the APC on 3/10/2013, 14/10/2013, 15/10/2013 and 16/10/2013. - Available at: 〈http://www.armscomm.gov.za/hearings> Accessed on 20 January 2014; AMD op. cit.

58 Armscor op. cit., p. 2.

${ }^{59}$ Schür op. cit., p. 6; AMD op. cit., p. 3.

${ }^{60}$ CJ Ferreira. Testimony at the APC on 11/11/2013, 12/11/2013, 13/11/2013, 14/11/2013, 15/11/2013 and 18/11/2013. Available at:

61 AMD op. cit.

<http://www.armscomm.gov.za/hearings> Accessed on 15 January 2014.

${ }^{62} \mathrm{G}$ Eliasson. Advanced public procurement as industrial policy: The aircraft industry as a technical university. New York: Springer, 2010. 
${ }^{63}$ See "Success Story: South Africa." Gripen News. Available at: http://www.saabgroup.com/Global/Documents percent20and percent20Images/Air/Gripen/Gripen percent 20product percent20sheet/Gripen_SuccessStory_SA.pdf. > Accessed on 1 December 2016; See also Burger op. cit.

${ }^{64}$ This would entail for the life of this aircraft over the total production run that was estimated around 500 aircraft.

${ }^{65}$ Schür op. cit., p. 6 (also Endnote 54 op. cit., p. 13).

${ }^{66}$ The usable life of a fighter aircraft is at least 20 years.

${ }^{67}$ See $<$ http://www.csir.co.za $>$ Accessed on 1 December 2016. Denel has been involved in a co-development programme on the A-Darter with Brazil.

${ }^{68}$ See $<$ http://www.saabgroup.com/... $>$ Accessed on 1 December 2016.

${ }^{69}$ AMD op.cit., p. 3.

${ }^{70}$ Gerber op.cit., p. 5.

${ }^{71}$ DBSA Social Accounting Matrices (SAMS), <http://www.dbsa.org/EN/DBSAOperations/Proj/Tools/Pages/SAMS.aspx>, as well as Statistics South Africa National Accounts, see <http://www.statssa.gov.za/publications/Report-0403-02/Report-04-03-022005.pdf> Accessed on 1 December 2016.

72 The EIA was done with the assistance of Ben van der Merwe from Urban-Econ, Development Economists, a consulting firm on local economic development, Pretoria. Van Dyk provided data for the NSAM model.

${ }^{73}$ Based on the National Social Accounting Matrix (2004 updated to 2013) of the Development Bank of Southern Africa.

${ }^{74}$ For example, Saab, Sweden; Thales, France; The Airbus Group, Germany; MTU, Germany; BAE Systems, UK; Rheinmetall, Germany; Turbomecca (SAFRAN), France. (Carl Zeiss later sold its share in Denel Optronics to Cassidian and BAE Systems sold its share in BAE Land Systems to Denel) see Table 9 in Chapter 7 of Van Dyk, 2015.

${ }^{75}$ Armscor op. cit., p. 2.

${ }^{76}$ SIPRI op cit. Table 1: The economic impact assessment of the SDP's DIP, p. 2.

${ }^{77}$ See Defence Review 2014: Chapter 15-8, par 54d.

${ }^{78}$ Although the 1997 DIP policy was updated on several occasions, it was rewritten in 2012. Key changes were introduced, stating that foreign local defence companies can no longer qualify for DIP activities, and a 100 percent nonperformance penalty.

${ }^{79}$ Refer to chapters 8, 9, 10 and 11 of Van Dyk op. cit., pp. 1 and 4 for more comprehensive arguments and conclusion regarding the SDP's DIP available at $\langle$ http://www.countertrade-offsets.com $>$ Accessed on 1 December 2016. 